\title{
Fasting C-Peptide Response, and Its Clinical Impact in Type I Diabetics to a Novel Metaphysical Energy Healing Therapy- Preliminary Experience and Observations
}

\author{
C. V. Krishnaswami*, Ramesh Chandrasekaran, Deepa Krishnaswami, A. Ganesan, \\ B. Sampoornam, Saroja Srinivasan, A. Srivasta, Shobana Anojan, V. Rajan Iyer
}

TAG-VHS Diabetes Research Centre (A Unit of Voluntary Health Services Diabetes Department), Chennai, India

Email: "info@tagvhsdrc.com, "drcvkrishnaswami@gmail.com, "cvk@diabetopaedia.com

Received 27 January 2016; accepted 23 February 2016; published 26 February 2016

Copyright @ 2016 by authors and Scientific Research Publishing Inc.

This work is licensed under the Creative Commons Attribution International License (CC BY). http://creativecommons.org/licenses/by/4.0/

\section{Abstract}

Type 1 diabetes is classically the true form of insulinopaenic diabetes usually occurring in young children below the age of 15 years and occasionally up to 20 years and characterised by very low/ negligible fasting $\mathrm{C}$-peptide in their blood due to extensive irreversible Beta cell damage. T1DM probably accounts for $5 \%$ to $10 \%$ of all diagnosed diabetes. The worldwide prevalence of T1DM is $0.1 \%$ to $0.3 \%$, with 78,000 new cases every year, especially among young individuals ( $<5$ years). According to BMC Public Health publication in 2015 T1D incidence was larger in males than in females in those aged $>15$. Type I diabetes is very much lower (20 times) in countries like Japan and India, than the western countries. The European Nicotinamide Diabetes Intervention Trial (ENDIT) is focused on the use of nicotinamide in the prevention of diabetes. In high doses (nicotinamide), it may cause a degree of sedation, a feeling of depression, and in very large dosages, liver toxicity. Because the vitamin cannot be marketed as a drug, the study is not getting a great deal of support from pharmaceutical companies. GAD antibodies (GADA) are a major diagnostic marker for Type 1 diabetes. Phase II clinical trials of a vaccine containing alum and recombinant GAD65, an auto antigen involved in type 1 diabetes, were promising, as of 2014 Phase III trial had failed. In our quest for improving the clinical condition \& quality of life of type I DM \& also to reduce the economic burden on them, we have embarked on a novel metaphysical energy therapy which we have been trying for the past 3 years at our research Centre. We have so far treated some 15 cases with this DAMM therapy. Among the 15 cases, 6 cases have shown significant improvement in fasting C-peptide levels. With the advent of this new modality of treatment (DAMM Therapy) the cost of treatment will be greatly reduced. This DAMM Therapy apparently has no side effects. This mode

${ }^{*}$ Corresponding author.

How to cite this paper: Krishnaswami, C.V., et al. (2016) Fasting C-Peptide Response, and Its Clinical Impact in Type I Diabetics to a Novel Metaphysical Energy Healing Therapy-Preliminary Experience and Observations. Journal of Diabetes Mellitus, 6, 90-99. http://dx.doi.org/10.4236/jdm.2016.61010 


\title{
of treatment will open a new light in the world of Type I diabetes.
}

\author{
Keywords
}

\section{J.I.I.D.M., T1DM, IDDM, ENDIT, GAD65, GADA, DAMM Therapy}

\section{Introduction}

Type 1 diabetes is classically the true form of insulinopaenic diabetes usually occurring in young children below the age of 15 years and occasionally up to 20 years and characterised by very low/negligible fasting C-peptide in their blood due to extensive irreversible Beta cell damage (of whatever aetiology) or surgical removal [1].

T1DM probably accounts for $5 \%$ to $10 \%$ of all diagnosed diabetes. The worldwide prevalence of T1DM is $0.1 \%$ to $0.3 \%$, with 78,000 new cases every year, especially among young individuals ( $<5$ years) [2]. The incidence, sex, seasonal and geographical patterns of juvenile-onset insulin-dependent diabetes mellitus (j.i.d.m.) were studied retrospectively on one third of the Danish population 1970-1974. The j.i.d.m. incidence seemed to show socioeconomic differences, being highest in those parts of the survey area with lower status [3].

In November 1972 the British Diabetic Association sponsored a register to which notification was invited of all new cases of diabetes occurring in children aged 0 - 15 years in Great Britain and Ireland. Notification suggested that there was a minimum yearly incidence of 7 - 67 cases per 100,000. The age distribution was bimodal with a main peak at about 11 years and a secondary peak at about 5 years. The sex ratio showed a male excess from 0 - 4 years and from 11 - 15 years and a female excess from 5 - 10 years [4]. In England the overall yearly incidence of newly diagnosed insulin-dependent diabetes mellitus in people under 21 was 15.6 cases/100,000 [5].

In a prospective epidemiological study conducted in Switzerland between (1991-1999) the authors found that the annual incidence of childhood diabetes had increased from 7.8/100,000 in 1991 to 10.6/100,000 in 1999, corresponding to annual average increase of $5.1 \%$. The most striking was the increased incidence in the $0-4$ years age group, which had risen from 2.4 to 10.5/100,000, corresponding to an average yearly increase of 23.8\%. The 0 - 4 years age group alone was responsible for the rise in the childhood Type 1 diabetes in the 10 years of follow-up [6].

According to BMC Public Health publication in 2015 T1D incidence was larger in males than in females in those aged $>15$. Professor M'Banya points out in his editorial that, people with type 1 diabetes worldwide are still dying because of missed diagnoses or inadequate insulin supply [7].

Type I diabetes is very much lower (20 times) in the oriental countries like Japan and India, both with similar high carbohydrate eating people, which have low incidence of J.I.I.D.M., than the western countries. In a epidemiology study conducted by CV. Krishnaswami and P. Chandra and the paper presented in International Symposium on epidemiology of Diabetes Mellitus at Sendai, Japan in the year 1982 of Type I DM (IDDM). In that study totally 156,258 people surveyed in Chennai corporation limits (urban area), there were 60,310 persons aged 0 - 20 years. According to statistics gathered from the survey the risk of JIDDM to be $<0.01 \%$. And the authors have suggested that this figure may rise to as much as $0.02 \%$ or $0.04 \%$, depending upon the regional variations in a vast multifaceted country like India [8].

The European Nicotinamide Diabetes Intervention Trial (ENDIT) is focused on the use of nicotinamide (also called niacinamide, or vitamin B3) in the prevention of diabetes. Nicotinamide is the amide form of nicotinic acid and has been used as a therapy for hypercholesterolemia. When given in doses 50 to 100 times higher than the recommended daily allowance, the vitamin, an antioxidant, seems to prevent oxygen free radicals from damaging beta cells in the pancreas [9].

Nicotinamide is readily available and generally considered very safe (although) "in high doses (nicotinamide), it may cause a degree of sedation, a feeling of depression, and in very large dosages, liver toxicity." Side effects may include headaches and rashes. Because the vitamin cannot be marketed as a drug, the study is not getting a great deal of support from pharmaceutical companies [10].

The discovery of GAD65 (Glutamic Acid Decarboxylase 65) as one of the first islet auto antigens in the pathogenesis of type 1 diabetes was a breakthrough that enabled study of specific autoimmune responses. GAD antibodies (GADA) are a major diagnostic marker for Type 1 diabetes [11]. 
GAD is a protein found in the brain and neural tissue, as well as the pancreatic islets. Autoantibodies to GAD (GADA) are present in up to $90 \%$ of children and adolescents who develop Type 1 diabetes, but are also common in people who develop diabetes before the age of 40 years. GADA associated with type 1 diabetes recognize predominantly the form of GAD found in pancreatic islets (GAD65); GADA persist for many years after diagnosis in a sizable proportion of patients with Type 1 diabetes, and can therefore help in characterizing diabetes in long-standing patients. Vaccines to treat or prevent Type 1 diabetes are designed to induce immune tolerance to insulin or pancreatic beta cells [12]. While Phase II clinical trials of a vaccine containing alum and recombinant GAD65, an autoantigen involved in type 1 diabetes, were promising, as of 2014 Phase III trial had failed [13].

In our quest for improving the clinical condition \& quality of life of people with type I DM \& also to reduce the economic burden on them, which will particularly benefit the countries with developing economies such as (Sub-Saharan Africa), we have embarked on a novel metaphysical energy therapy which we have been trying for the past 3 years at our research centre.

\section{Case Presentation}

We have so far treated some 15 cases and the following Table 1 and bar code Graph 1 shows (C-peptide levels), Graph 2 shows (wt, insulin/oral drug dosage) with this DAMM therapy for children.

\section{Methods and Materials}

All the 15 cases treated were with our new metaphysical energy therapy. The new healing modality being researched at the TAG VHS DRC (which we have termed Dynamic Acupuncture Mediated Metaphysical(DAMM) Therapy) is a manifestation of physical energy of healing, attained through a severe and deep understanding and training several forms of energy, cum metaphysical practices plus an incredible gift with prodigious practice done by our therapist Mr. Rajan Iyer. The DAMM therapy is a unique novel way of infusing and transferring healing energy from the environment (cosmos) through the therapist, to the patient. We were amazed to find among the 15 patients treated 5 of them had increased fasting C-peptide levels after treatment.

\section{Results}

Among the 15 cases of Type I diabetics who were treated with DAMM Therapy, 6 cases in the ratio of 2:1 (with patient ID 2285, 3072, 3620, 3235, 3081 and 3782) have shown significant improvement in the fasting c peptide levels. In the case of Master.D with ID (2285) whose fasting c peptide level before treatment was $0.888 \mathrm{mU} / \mathrm{L}$, and after treatment it has increased significantly to $2.35 \mathrm{mU} / \mathrm{L}$. In the case of Ms.M.C with ID (3072) whose fasting c peptide level before treatment was $0.10,0.05,0.10,0.01$ and after treatment it has increased significantly to $0.16 \mathrm{mU} / \mathrm{L}$. For Master.T (3620) whose fasting c peptide level before treatment was f.cep- $0.27 \mathrm{mU} / \mathrm{L}$, $0.35 \mathrm{mU} / \mathrm{L}$ and after treatment it has increased significantly to $0.10 \mathrm{mU} / \mathrm{L} 0.76 \mathrm{mU} / \mathrm{L}$. For Mr.H M d (3235) fasting c peptide level before treatment was F C-Pep $0.165 \mathrm{mU} / \mathrm{L}$ and after treatment it has increased significantly to F C-Pep-0.87 mU/L. Mrs.D (3081) whose fasting c peptide level before treatment was f.cep $1.16 \mathrm{mU} / \mathrm{L}$ and after treatment it has increased significantly to $1.68 \mathrm{mU} / \mathrm{L}$ and for Ms.S wit ID (3782) whose fasting c peptide level before treatment was $0.12,0.37,1.31 \mathrm{mU} / \mathrm{L}$ and after treatment it has increased significantly to 0.28 , $0.76 \mathrm{mU} / \mathrm{L}$.

\section{Discussion}

The needs of the people with type 1 diabetes are different from those of the majority of people with diabetes and have to be addressed separately. In patients with T1DM, poor glycaemic control before CABG was associated with increased long-term risk of death or MACE [14].

Lack of access to, and the high cost of, insulin and other supplies, limited health professional expertise concerning childhood diabetes, lack of diabetes education, geographic isolation and extreme poverty can result in very poor outcomes—starting with frequent misdiagnosis at disease onset so the child dies untreated; then a high risk of early death from hypoglycaemia or ketoacidosis; and for those who survive, very poor blood glucose control. Such sustained poor control leads to impaired quality of life and develop severe complications (such as loss of vision, end-stage renal failure and severe neuropathy) in their 20s or even earlier [8]. 
Table 1. Shows detailed case records of patients with Type I Diabetes.

\begin{tabular}{|c|c|c|c|c|c|c|c|c|}
\hline S. No & $\begin{array}{c}\text { Name/ } \\
\text { patient ID. }\end{array}$ & Age/sex & Diagnosis/year & C-peptide & $\begin{array}{l}\text { Dose of } \\
\text { insulin }\end{array}$ & $\begin{array}{l}\text { Previous } \\
\text { weight }\end{array}$ & $\begin{array}{l}\text { Present } \\
\text { weight }\end{array}$ & $\begin{array}{l}\text { Total } \\
\text { session of } \\
\text { damm. }\end{array}$ \\
\hline 1 & $\begin{array}{l}\text { Master. D } \\
\text { (2285) }\end{array}$ & $11 \mathrm{yrs} / \mathrm{M}$ & $\begin{array}{c}{ }^{*} \text { T1DM } \\
\text { 20-05-2013 }\end{array}$ & $\begin{array}{c}\text { Before-F Cep-0.888, } \\
\text { 2.46, 1.31, 2.58 mU/L } \\
\text { After-2.35, 2.24, } 1.47\end{array}$ & Novomix $3024 \mathrm{U}$ & 35.9 & 46.3 & 5 \\
\hline 3 & $\begin{array}{l}\text { Ms.M.S } \\
\text { (438) }\end{array}$ & 19 yrs/F & $\begin{array}{l}\text { "T1DM } \\
2006\end{array}$ & $\begin{array}{c}\text { Before }-0.04,0.10 \mathrm{mU} / \mathrm{L} \\
\text { After-0.039 }\end{array}$ & $\begin{array}{l}\text { Human Mixtard } \\
\text { 30/70 44U }\end{array}$ & 38.3 & 46.8 & 3. \\
\hline 4 & $\begin{array}{l}\text { Ms.S } \\
(3782)\end{array}$ & $\begin{array}{l}22 \mathrm{yrs} / \mathrm{F} \\
2014\end{array}$ & $\begin{array}{l}{ }^{*} \text { Diabetic Ketosis- } \\
\text { reversed } \\
{ }^{*} \text { Type } 1 \text { Diabetes } \\
\text { Mellitus (Diagnosed } \\
\text { in September 2014) }\end{array}$ & $\begin{array}{c}\text { Before-F.Cep-0.12, } \\
0.37,1.31 \mathrm{mU} / \mathrm{L} \\
\text { After-0.28, } 0.76 \mathrm{mU} / \mathrm{L}\end{array}$ & $\begin{array}{l}\text { Inj: Human Mixtard } \\
\text { 30/70 HM-45U }\end{array}$ & 48.9 Kgs & 48.7 Kgs & 3 \\
\hline 5 & Ms.D (26) & $\begin{array}{c}24 \mathrm{yrs} / \mathrm{F} \\
11-10-2002\end{array}$ & ${ }^{*} \mathrm{~T} 1 \mathrm{DM}$ & $\begin{array}{c}\text { Before }-0.8,0.5 \\
\quad 0.667 \mathrm{mU} / \mathrm{L} \\
\text { After- }-0.10,0.01 \mathrm{mU} / \mathrm{L}\end{array}$ & $\begin{array}{l}\text { Human Mixtard } \\
\text { 30/70 40U }\end{array}$ & 32 Kgs & 48.6 Kgs & 2 \\
\hline 6 & $\begin{array}{l}\text { Master.T } \\
(3620)\end{array}$ & $14 \mathrm{yrs} / \mathrm{M}$ & ${ }^{*} \mathrm{~T} 1 \mathrm{DM}$ & $\begin{array}{c}\text { Before-f.cep-0.27, } \\
\quad 0.35 \mathrm{mU} / \mathrm{L} \\
\text { After-0.10, } 0.76 \mathrm{mU} / \mathrm{L}\end{array}$ & $\begin{array}{l}\text { Human mixtard: } \\
\text { 30/70 - 20U }\end{array}$ & 28.3 & 32 kgs & 4 \\
\hline 7 & $\begin{array}{l}\text { MS.S } \\
(4191)\end{array}$ & $\begin{array}{l}22 \mathrm{yrs} / \mathrm{F} \\
2009\end{array}$ & $\begin{array}{c}{ }^{*} \text { T1DM } \\
{ }^{*} \text { ACUTE } \\
\text { PANCREATITIS }\end{array}$ & BF-c-pep-0.83 & Inj. Human Mixtard 25U & $44.9 \mathrm{Kgs}$ & $44.5 \mathrm{Kgs}$ & 10 \\
\hline 8 & Mr.S (956) & $\begin{array}{c}47 \mathrm{yrs} / \mathrm{M} \\
25-07-1985\end{array}$ & ${ }^{*} \mathrm{~T} 1 \mathrm{DM}$ & $\begin{array}{c}\text { Before- }-0.82,0.82, \\
0.181 \\
\text { After- }-0.45,0.82,0.10\end{array}$ & $\begin{array}{c}\text { H. Actrapid } \\
\text { 22U Insulatard 18U }\end{array}$ & $70.7 \mathrm{~kg}$ & & 2 \\
\hline 9 & $\begin{array}{l}\text { MS.S } \\
(4298)\end{array}$ & $\begin{array}{l}12 \mathrm{yrs} / \mathrm{F} \\
\text { Apr-15 }\end{array}$ & ${ }^{*} \mathrm{~T} 1 \mathrm{DM}$ & BF-F.C-Pep- 0.47 & Inj.HM-25U & 35.3 kgs & 35.8 kgs & 10 \\
\hline 10 & $\begin{array}{l}\text { Mr.HMd } \\
\text { (3235) }\end{array}$ & 35 yrs/M & $\begin{array}{c}{ }^{*} \text { Chronic Calculous } \\
\text { pancreatitis } \\
{ }^{*} \text { FCPD } \\
{ }^{*} \text { IRDM }\end{array}$ & $\begin{array}{c}\text { Before-FC-Pep-0.165 } \\
\text { After-FC-Pep-0.87 } \\
\text { mU/L }\end{array}$ & $\begin{array}{l}{ }^{*} \text { Humolog 80u (BF) } \\
{ }^{*} \text { Inj:Glargine 20u (BT) }\end{array}$ & 67.8 & 67.1 & 7 \\
\hline 11 & $\begin{array}{l}\text { Master.D } \\
\text { (3353) }\end{array}$ & $5 \mathrm{yrs} / \mathrm{M}$ & $\begin{array}{c}\text { *IDDM } \\
{ }^{*} \text { Megaloblasticanemia } \\
\text { * Red cell hypoplasia. } \\
{ }^{*} \text { Speech and hearing- } \\
\text { impaired. }\end{array}$ & $\begin{array}{l}\text { Before-FC-Pep-0.2, } \\
0.29 \mathrm{mU} / \mathrm{L}\end{array}$ & $\begin{array}{l}\text { Human Mixtard } \\
\text { 30/70 4u (pre BF) }\end{array}$ & 13.6 & 13.4 & 9 \\
\hline 12 & $\begin{array}{c}\text { Mr.N } \\
(3182)\end{array}$ & $21 \mathrm{yrs} / \mathrm{M}$ & $\begin{array}{c}{ }^{*} \mathrm{~T} 1 \mathrm{DM} \\
{ }^{*} \text { Mental Retartation }\end{array}$ & Before-Fc—0.98 mU/L & $\begin{array}{l}\text { Human 30/70 } \\
\text { Mixtard 22U }\end{array}$ & $49.1 \mathrm{~kg}$ & & 5 \\
\hline 13 & $\begin{array}{l}\text { Mrs.D } \\
\text { (3081) }\end{array}$ & $28 \mathrm{yrs} / \mathrm{F}$ & *MODY & $\begin{array}{c}\text { Before-FcPep-1.16 } \\
\text { mU/L } \\
\text { After-1.68 mU/L }\end{array}$ & $\begin{array}{l}\text { Tab XL (Glipizide) } \\
10 \text { mg 1-1-15 mins } \\
\text { Before Food }\end{array}$ & 65.6 & 65.6 & 10 \\
\hline 14 & $\begin{array}{l}\text { Ms.G } \\
(1078)\end{array}$ & $15 \mathrm{yrs} / \mathrm{F}$ & ${ }^{*}$ MODY & $\begin{array}{c}\text { Before: FC-Pep-0.92, } \\
\text { 2.91, 1.14, 1.99, } 1.45 \\
\mathrm{mU} / \mathrm{L} \\
\text { After Therapy-FC-Pep } \\
\text { 1.05 mU/L }\end{array}$ & $\begin{array}{l}\text { Tab Glimiperide (BF), } \\
\text { Inj:Novomix 26U (BF), } \\
\text { Glargine 20U (BT) }\end{array}$ & 44.5 & 44.8 & 2 \\
\hline 15 & $\begin{array}{l}\text { Ms.S } \\
(2897)\end{array}$ & $13 \mathrm{yrs} / \mathrm{F}$ & $\begin{array}{l}{ }^{*} \mathrm{~T} 1 \mathrm{DM} \\
{ }^{*} \text { Hypothyroidism }\end{array}$ & $\begin{array}{c}\text { Before-FC Pep-0.3, } \\
\text { 0.9, } 0.1 \\
\text { After-FC Pep-0.1 }\end{array}$ & $\begin{array}{c}\text { Human Mixtard } \\
\text { 30/70 - 36U }\end{array}$ & 41.7 kgs & 41.2 kgs & 1 \\
\hline
\end{tabular}



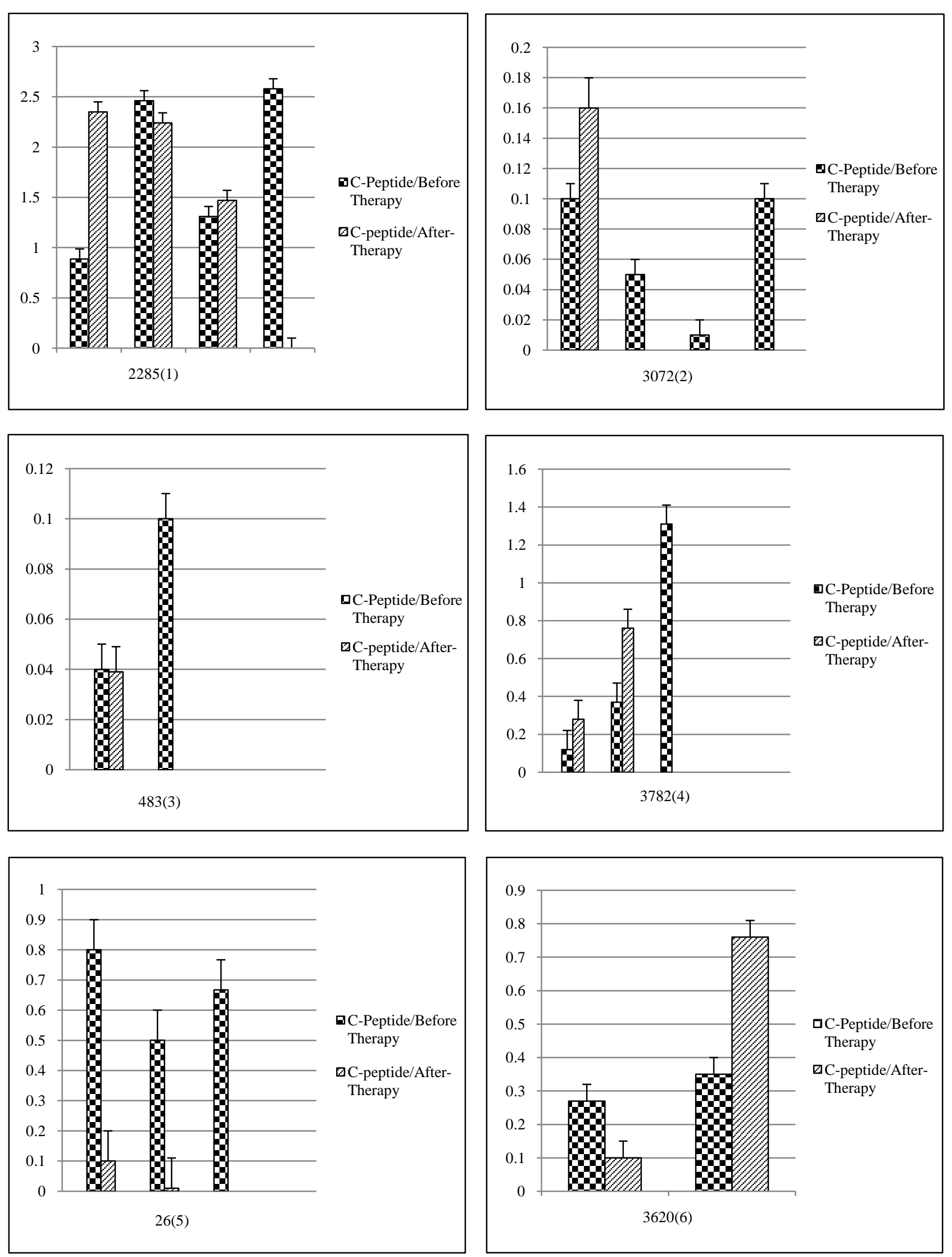
C. V. Krishnaswami et al.
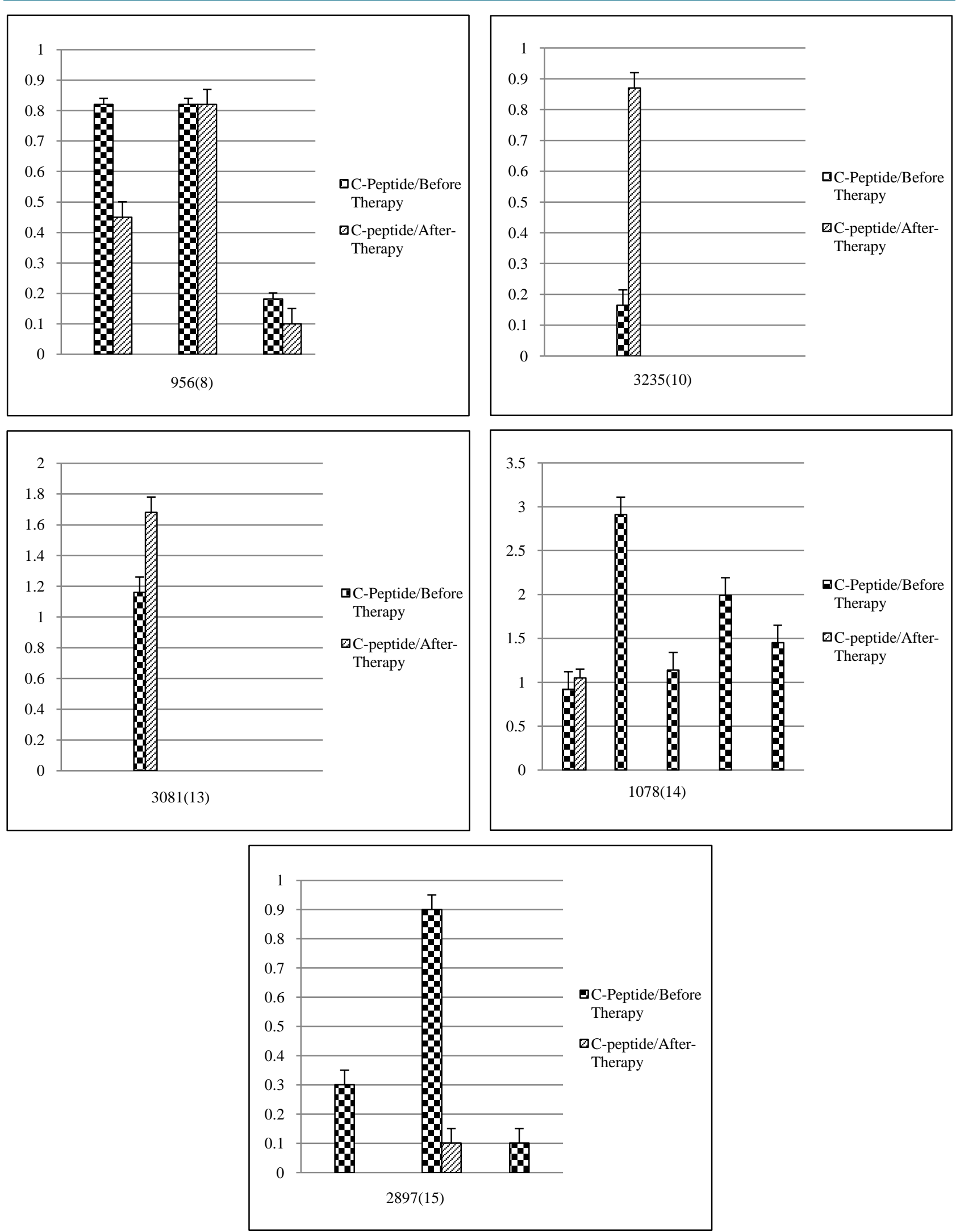

Graph 1. Illustrates the C-peptide levels before and after DAMM therapy. 

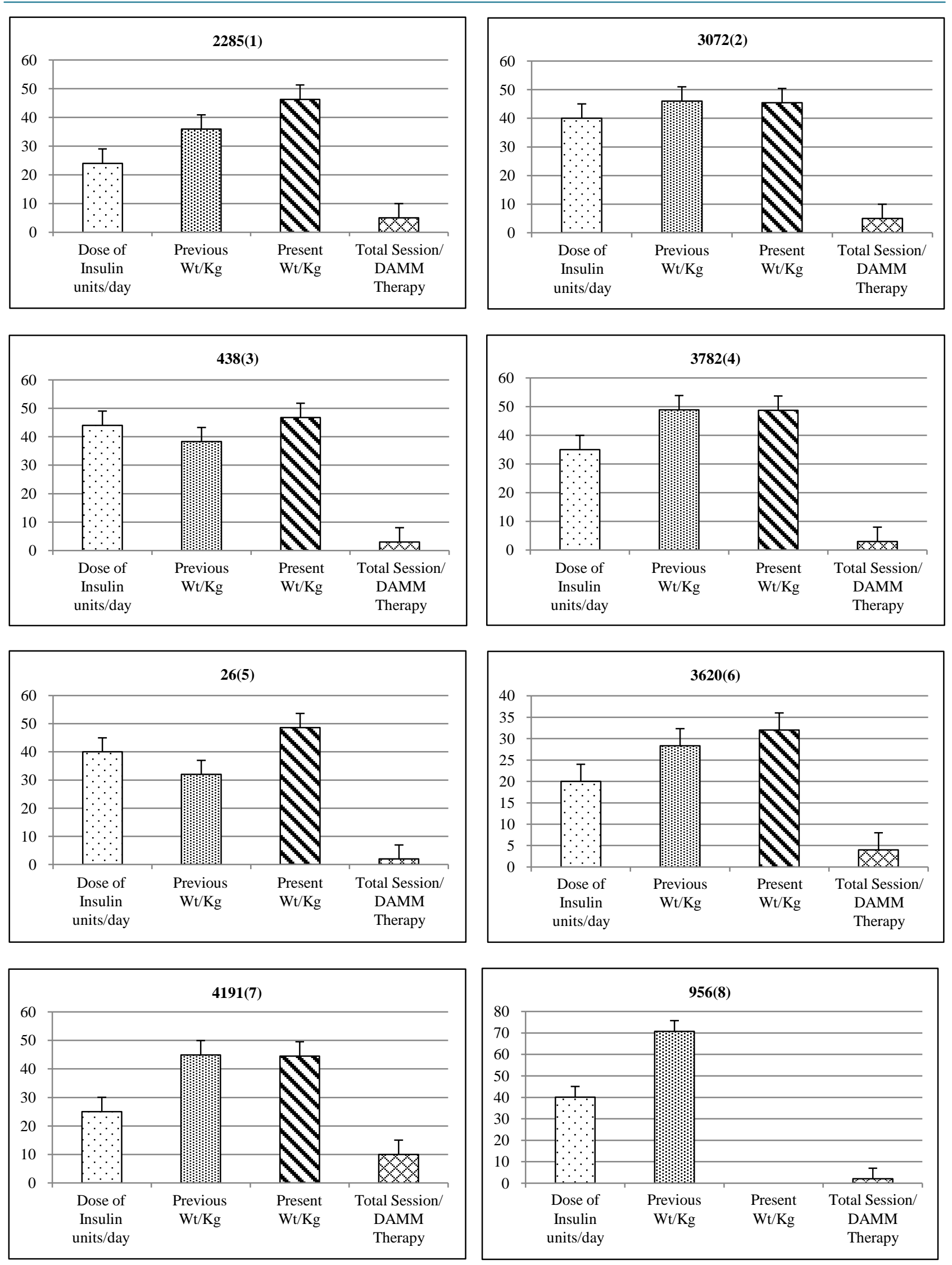

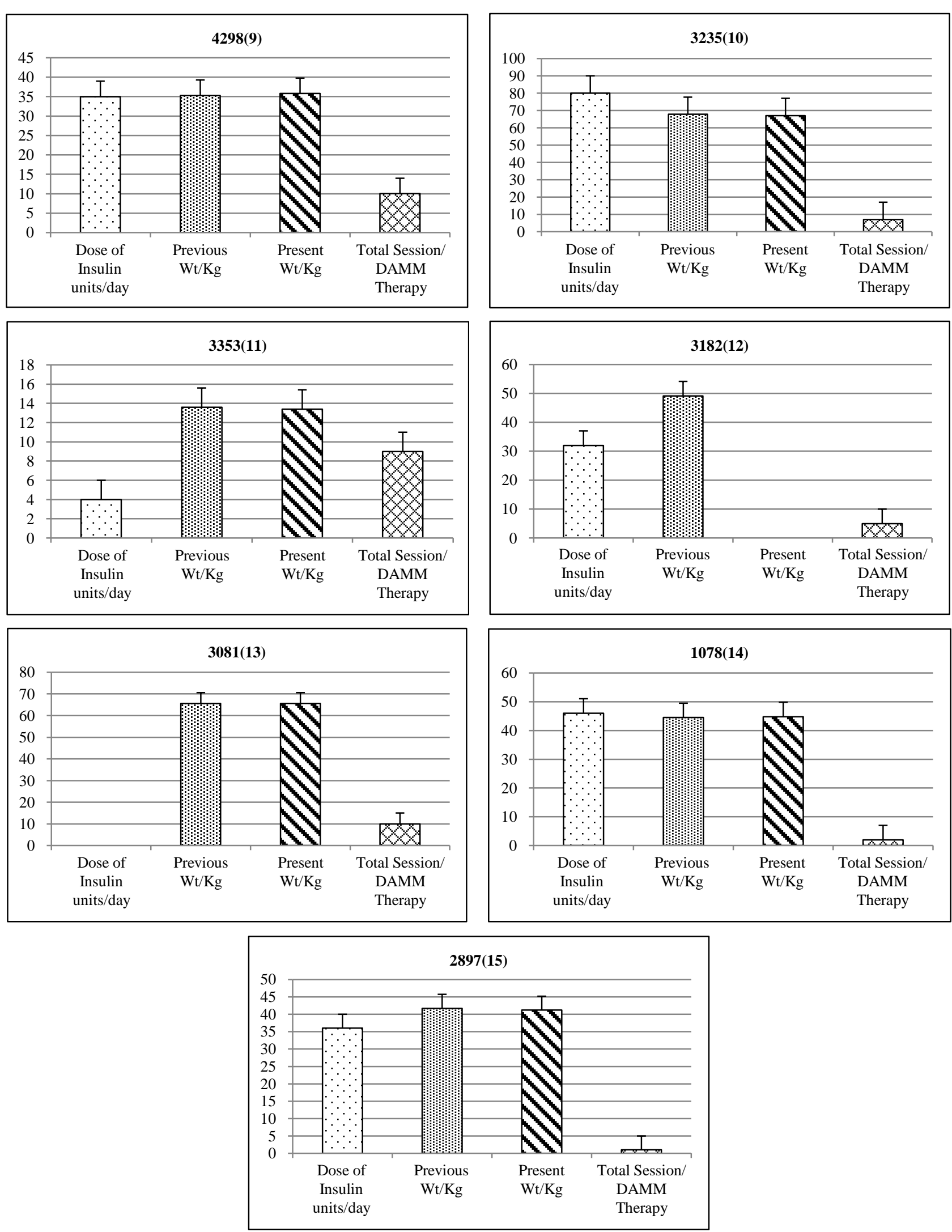

Graph 2. Shows insulin dosage, previous/present weight and total session of DAMM therapy. 
But with the advent of this new modality of treatment (DAMM Therapy) the cost of treatment will be greatly reduced. The new healing modality that is being researched at the TAG VHS DRC [15], which we have termed Dynamic Acupuncture Mediated Metaphysical Therapy (DAMM) is an manifestation of physical energy of healing, attained through a subtle thorough understanding and a gift strengthened through a tremendous background of practice done by our therapist V. Rajan Iyer. The DAMM therapy is a unique\& novel way of infusing and transferring healing (cosmic) energy from the environment through the therapist to the patient with apparently no side effects [16].

In this study with this new mode of treatment we could find out the improvement in fasting C-peptide levels, weight of the subjects with minimum sittings of DAMM Therapy and medium dosage of insulin intake. For example the subjects with ID (2285, 3072, 3620, 3235, 3782 whose fasting C-peptide levels and weight has been improved considerably with 20 - 40 units on Insulin/day except for 3235 whose insulin dosage was 80 U/day. Apart from this one subject with ID 3081 who was not taking insulin, but on oral medication needed 10 sittings of DAMM therapy for showing improvement in fasting C-peptide level. We could attribute this different result to different type of diabetes (MODY) and late age of onset (28 years) and probably due to consuming of oral medications for diabetes. Even then the new modality of treatment (DAMM Therapy) was found to be effective in improving fasting C-peptide levels.

\section{Conclusion}

The patients are not regular. We are yet to standardise for true \& sustained response for what is amazing \& unique that most people who received this therapy have experienced hypoglycaemic response necessitating insulin reduction by various amounts. This is independent of the C-Peptide rise. One of the patients could even get (14 years old Master T) off Insulin for 20 days but had to get on to small dose of insulin, but he is unfortunately lost for follow up. There are many unanswered questions which require, a detailed in-depth analysis, investigation, honest introspection, and interpretation. But for the present, what we have definitely understood is, that this approach can if supported munificently, could produce a massive \& transparent data, which could shake the medical world! The multimillion dollar question however is, will any one person or group in the world support this gigantic effort with honest compassion to help the juvenile insulin dependent diabetic children?

\section{Acknowledgements}

1) We thank Prof. S Suresh Honorary Secretary, VHS, Chennai for his cooperation.

2) We thank Prof. B. M. Hegde, Our Co-Chairman and Director Clinical Research \& Energy Medicine division and former Vice-chancellor, Manipal, University, Mangalore, whose inspirational guidance and help and introduction of the concept of intracellular Energy Balance and "Wisdom of the Human Body" has taken us to the successful Journey so far, and resulted in this important observational research paper.

3) The team of specialist nurses led by Y. Ramalakshmi and Subhashini, paramedical team, and IT support group (Health Track Info. Solution) for following up this case, documentation and preparation of this paper.

4) All our donors who support the research endeavours at TAG VHS DRC since 2011.

\section{References}

[1] Gale, E.A.M. (2014) Pancreatic Disorders. http://www.diapedia.org/

[2] Lorenzo, P. (2011) Estimating the Worldwide Burden of Type 1 Diabetes. http://www.idf.org/

[3] Christau, B., Kromann, H., Andersen, O.O., Christy, M., Buschard, K., Arnung, K., Kristensen, I.H., Peitersen, B., Steinrud, J. and Nerup, J. (1977) Incidence, Seasonal and Geographical Patterns of Juvenile-Onset Insulin-Dependent Diabetes Mellitus in Denmark. Diabetologia, 13, 281-284. http://dx.doi.org/10.1007/BF01223266

[4] Bloom, A., Hayes, T.M. and Gamble, D.R. (1975) Register of Newly Diagnosed Diabetic Children. British Medical Journal, 3, 580-583. http://dx.doi.org/10.1136/bmj.3.5983.580

[5] Bingley, P.J. and Gale, E.A.M. (1989) Incidence of Insulin Dependent Diabetes in England: A Study in the Oxford Region, 1985-86. British Medical Journal, 298, 558-560. http://dx.doi.org/10.1136/bmj.298.6673.558

[6] Schoenle, E.J., Lang-Muritano, M., Gschwend, S., Laimbacher, J., Mullis, P.E., Torresani, T., Biason-Lauber, A. and Molinari, L. (2001) Epidemiology of Type 1 Diabetes Mellitus in Switzerland: Steep Rise in Incidence in under 5 Years Old Children in the Past Decade. Diabetologia, 4, 286-289. http://dx.doi.org/10.1007/s001250051615 
[7] Paula, A.D.V., Pierre, B. and Alain, J.V. (2015) Global Epidemiology of Type 1 Diabetes in Young Adults and Adults: A Systematic Review. BMC Public Health, 15, 255. http://dx.doi.org/10.1186/s12889-015-1591-y

[8] Krishnaswami, C.V. and Chandra, P. (1983) The Significance of Certain Epidemiological Variants in the Genesis of Juvenile Insulindependant Diabetes Mellitus-The Need for a Global Program of Co-Operation. Tohoku Journal of Experimental Medicine, 141, 161-170. http://dx.doi.org/10.1620/tjem.141.Suppl 161

[9] Gale, E.A., Bingley, P.J., Emmett, C.L. and Collier, T. (2004) European Nicotinamide Diabetes Intervention Trial (ENDIT) Group. European Nicotinamide Diabetes Intervention Trial (ENDIT): A Randomised Controlled Trial of Intervention before the Onset of Type 1 Diabetes. Lancet, 363, 925-931. http://dx.doi.org/10.1016/S0140-6736(04)15786-3

[10] George, E. (1995) Two Diabetes Prevention Trials Begin. https://www.diabeteshealth.com/

[11] Matthew, D. (2003) GAD in Metabolic \& Neurologic Disease. http://www.academia.edu/2705386/GAD_and_Parkinson_s_Disease

[12] Gale, E.A.M. (2014) GAD Antibodies. http://www.diapedia.org/type-1-diabetes-mellitus/21042821246/gad-antibodies

[13] Joseph, M.T. (2015) National Pancreas Foundation. https://www.pancreasfoundation.org/

[14] Nyström, T., Holzmann, M.J., Eliasson, B., Kuhl, J. and Sartipy, U. (2015) Glycemic Control in Type 1 Diabetes and Long-Term Risk of Cardiovascular Events or Death after Coronary Artery Bypass Grafting. Journal of the American College of Cardiology, 66, 535-543. http://dx.doi.org/10.1016/j.jacc.2015.05.054

[15] Rajan, V. (2014) Our New Research Initiative-Metaphysical Energy Medicine-Using Dynamic Acupuncture Mediated Metaphysical (DAMM) Therapy in Human Healing. TAG VHS DRC. http://www.tagvhsdrc.com/damm.asp

[16] Francesca, M.C. (2014) Body of Health: The New Science of Intuition Medicine for Energy \& Balance. Energy Medicine University, 117. http://www.energymedicineuniversity.org 